\title{
RaxH/RaxR: A Two-Component Regulatory System in Xanthomonas oryzae pv. oryzae Required for AvrXa21 Activity
}

\author{
Saul Burdman, ${ }^{1}$ Yuwei Shen, ${ }^{2}$ Sang-Won Lee, ${ }^{3}$ Qinzhong Xue, ${ }^{3}$ and Pamela Ronald ${ }^{3}$ \\ ${ }^{1}$ Department of Plant Pathology and Microbiology, Faculty of Agricultural, Food and Environmental Quality Sciences, The \\ Hebrew University of Jerusalem, P.O.Box 12, Rehovot 76100, Israel; ${ }^{2} D N A$ LandMarks Inc., 84 Richelieu, St-Jean-sur- \\ Richelieu, Quebec J3B 6X3, Canada; ${ }^{3}$ Department of Plant Pathology, University of California, One Shields Avenue, Davis, \\ CA 95616, U.S.A.
}

Submitted 9 September 2003. Accepted 18 January 2004.

Xanthomonas oryzae pv. oryzae is the causal agent of bacterial leaf blight, one of the most serious diseases in rice. $X$. oryzae pv. oryzae Philippine race 6 (PR6) strains are unable to establish infection in rice lines expressing the resistance gene $\mathrm{Xa21}$. Although the pathogen-associated molecule that triggers the $\mathrm{Xa21}$-mediated defense response (AvrXa21) is unknown, six rax (required for AvrXa21 activity) genes encoding proteins involved in sulfur metabolism and Type I secretion were recently identified. Here, we report on the identification of two additional $\operatorname{rax}$ genes, $\operatorname{rax} R$ and $\operatorname{raxH}$, which encode a response regulator and a histidine protein kinase of two-component regulatory systems, respectively. Null mutants of PR6 strain PXO99 that are impaired in either $\operatorname{raxR}, \operatorname{rax} H$, or both cause lesions significantly longer and grow to significantly higher levels than does the wild-type strain in Xa21-rice leaves. Both raxR and $\operatorname{raxH}$ mutants are complemented to wild-type levels of AvrXa21 activity by introduction of expression vectors carrying $\operatorname{raxR}$ and $\operatorname{raxH}$, respectively. These null mutants do not affect AvrXa7 and AvrXa10 activities, as observed in inoculation experiments with Xa7- and Xa10rice lines. Western blot and $\mathrm{raxR} / \mathrm{g} f \mathrm{p}$ promoter-reporter analyses confirmed RaxR expression in $X$. oryzae pv. oryzae. The results of promoter-reporter studies also suggest that the previously identified $\operatorname{raxSTAB}$ operon is a target for RaxH/RaxR regulation. Characterization of the RaxH/RaxR system provides new opportunities for understanding the specificity of the $X$. oryzae pv. oryzae-Xa21 interaction and may contribute to the identification of AvrXa21.

Genetic factors governing interactions between pathogens and their host plants determine disease resistance or susceptibility. This genetic pattern is the basis of the "gene-for-gene" hypothesis, which states that plant disease resistance is controlled by a resistance $(R)$ gene that encodes a product that

Corresponding author: Pamela Ronald; E-mail: pcronald@ucdavis.edu; Telephone: +1-530-7521654; Fax: +1-530-7525674.

Nucleotide sequence data are available in the GenBank database under accession number AY237357.

* The $\boldsymbol{e}$-Xtra logo stands for "electronic extra" and indicates the HTML abstract available on-line contains supplemental figures not included in the print edition. interacts (directly or indirectly) with an effector molecule encoded by a corresponding bacterial avirulence ( $a v r$ ) gene (Flor 1971). The gene-for-gene hypothesis has been shown to accurately describe the interactions between plant species and a large variety of pathogens, including viruses, bacteria, fungi, nematodes, and insects (Dangl and Jones 2001).

Most plant $R$ genes encode presumed intracellular proteins that are predicted to bind intracellular ligands possibly but not necessarily encoded by $a v r$ genes (Dangl and Jones 2001). In plant pathogenic bacteria, identification of mutant strains altered in their ability to cause disease and to induce a hypersensitive response (HR) led to the discovery of hrp (hypersensitive response and pathogenicity) genes (Alfano and Collmer 1997; Leach and White 1996; Lindgren et al. 1986). Several hrp genes encode membrane-associated proteins that form part of a Type III secretory pathway that is active during infection of the plant. Over the past several years, a number of bacterial Avr proteins have been identified that require the Type III apparatus for secretion. In contrast to the intracellular model, it appears likely that some $R$ gene products bind pathogenassociated molecules that are present in the extracellular environment. The tomato $C f 9$ gene product that mediates resistance to the fungal pathogen Cladosporium fulvum (Jones et al. 1994), the flagellin receptor Fls2 (Gomez-Gomez and Boller 2000), and the product of the rice $R$ gene $X a 21$ that confers resistance to several Xanthomonas oryzae pv. oryzae races (Song et al. 1995) best fit this model.

$X$. oryzae pv. oryzae is the causal agent of one of the most serious diseases of rice (Oryza sativa L.), bacterial leaf blight, which is responsible for significant reductions of rice yields in tropical, subtropical, and warm temperature regions. Xa21 encodes a presumed receptor kinase (RK), which confers resistance to multiple races of $X$. oryzae pv. oryzae (Wang et al. 1996). Xa21 belongs to the leucine-rich repeats (LRR) subclass of plant RK and contains an extracellular domain carrying imperfect units of 24-aa LRR (Song et al. 1995). The presumed extracellular LRR domain of Xa21 is responsible for recognition of specific $X$. oryzae pv. oryzae strains (Wang et al. 1998).

Six rax (required for AvrXa21 activity) genes from PXO99, a $X$. oryzae pv. oryzae Philippine race 6 (PR6) strain, were recently identified. In contrast to PXO99, which is unable to cause disease in rice lines expressing Xa21, PXO99 strains carrying rax gene mutations lose AvrXa21 activity (da Silva et al. 2004; Shen et al. 2002). Three of these genes, $\operatorname{raxA}, \operatorname{raxB}$, and $\operatorname{rax} C$, encode proteins that share similarity with compo- 
nents of Type I secretion systems of gram-negative bacteria. RaxA and RaxB show similarity with membrane fusion proteins and inner membrane permeases of the ATP-binding cassette (ABC) superfamily, respectively. RaxC is similar to the Escherichia coli outer membrane protein TolC (da Silva et al. 2004). Three additional $\operatorname{rax}$ genes encode proteins involved in sulfur metabolism. $\operatorname{rax} P$ and $\operatorname{rax} Q$ encode ATP sulfurylase and adenosine phosphosulfate kinase activities (Shen et al. 2002), whereas $\operatorname{rax} S T$ shares similarity with mammalian and bacterial sulfotransferases. $\operatorname{rax} S T$ is linked to $\operatorname{rax} A$ and $\operatorname{rax} B$, and results of sequence analyses suggest these genes are part of one operon named $\operatorname{raxSTAB}$ (da Silva et al. 2004). One or more presumed AvrXa21 molecules is yet to be identified.

Sequencing downstream of $\operatorname{rax} S T A B$ led to the identification of two open reading frames (ORF), $\operatorname{raxR}$ and $\mathrm{raxH}$, showing similarity to response regulators (RR) and histidine protein kinases (HK) of two-component regulatory (or signal transduction) systems. Two-component systems are present in both gram-negative and gram-positive bacteria and have been shown to regulate a wide variety of biological processes, including expression of toxins and other proteins related to virulence and pathogenicity (Grebe and Stock 1999; Stock et al. 2000; West and Stock 2001). In lactic acid bacteria, two-component systems regulate synthesis and type I secretion of bacteriocin-like peptides (small peptides, some of them having antimicrobial activity) (Nes and Eijsink 1999). Indeed, the $X$. oryzae pv. oryzae $\operatorname{rax} B$ product is most similar to $\mathrm{ABC}$ transporters involved in secretion of bacteriocin-like peptides, and $\operatorname{raxC}$ complements an $E$. coli tolC mutant strain for secretion of the bacteriocin colicin V (da Silva et al. 2004). In light of these findings, we investigated the role of $\operatorname{raxR}$ and $\operatorname{raxH}$ in the $X$. oryzae pv. oryzae-Xa21 interaction. In this report, we show that the RaxH/RaxR system is required for wild-type levels of AvrXa21 activity in X. oryzae pv. oryzae.

\section{RESULTS}

Sequencing of the $X$. oryzae pv. oryzae genomic region downstream of $\operatorname{raxSTAB}$.

A 9-kb Sau3AI fragment from clone p10.78 (Table 1), comprising the $\operatorname{rax} S T A B$ region from PR6 $X$. oryzae pv. oryzae
PXO99, was used as the probe to search an available cosmid genomic library of the PR6 strain PXO86 (Hopkins et al. 1992). Both strains are avirulent on Xa21 plants and share a very high level of identity. Clone pHMX7-10 carrying a fragment of about $25 \mathrm{~kb}$ was selected for subcloning and sequencing. Following restriction with EcoRI and ApaI, the resulting fragments were subcloned into pBluescript. Subclones pSKX312 and pSKX115, containing a 7,194-bp ApaI-EcoRI fragment and an approximately 4-kb EcoRI fragment, respectively, were partially sequenced, leading to a sequenced genomic region of about $15.5 \mathrm{~kb}$ (Fig. 1). The PXO99 9-kb fragment from p10.78 and the PXO86 sequenced region from pSKX312 (GenBank accession number AY237357) overlap over approximately $100 \mathrm{nt}$ with $100 \%$ identity. Sequence analysis lead to the completion of ORF10 (da Silva et al. 2004) and to the identification of at least four additional ORF designated ORF11 through ORF14 (Fig. 1).

\section{ORFs 13 and 14 encode a putative two-component system required for wild-type levels of AvrXa21 activity in X. oryzae pv. oryzae strain PXO99.}

The region comprising ORFs 11 to 14 shares a high level of similarity to genomic regions of the recently sequenced xanthomonads, $X$. axonopodis pv. citri and $X$. campestris pv. campestris. ORF11 and ORF12 encode putative proteins with unknown functions. ORF13 and ORF14 encode putative 238and 430-aa proteins, showing significant similarity to RR and HK of prokaryotic two-component regulatory systems, respectively.

PXO99 null mutants impaired in ORF13 and ORF14 were created by insertional mutagenesis and were designated PXO99R (RR) and PXO99H (HK), respectively. Various inoculation experiments using these strains in comparison with the parental strain PXO99 $\left(\mathrm{AvrXa} 21^{+}\right)$and the Korean race 1 (KR1) strain DY89031 (AvrXa21-) were carried out using the Oryza sativa subsp. japonica cultivars TP309 (susceptible control) and TP309-Xa21 (a transgenic rice line carrying the $\mathrm{Xa21}$ gene) plants. In all experiments, PXO99R and $\mathrm{PXO} 99 \mathrm{H}$ showed reduced AvrXa21 activity in comparison with wildtype PXO99 (Table 2). That is, 5 to 6 days after inoculation (dai), TP309-Xa21 leaves inoculated with the mutant strains

Table 1. Bacterial strains used in this study ${ }^{a}$

\begin{tabular}{|c|c|c|}
\hline Strain & Relevant characteristics & Source or reference \\
\hline \multicolumn{3}{|l|}{ Escherichia coli } \\
\hline DH10B & $\mathrm{F}^{-}$mcrA $\Delta(m r r-h s d R M S-m c r B C)$ Ф80lacZ $\Delta \mathrm{M} 15 \Delta$ lacX74 deoR recA1 endA1 ara & \\
\hline & $\Delta 139 \Delta($ ara, leu $) 7697$ galU galK $\lambda^{-} \operatorname{rpsL}\left(\mathrm{Sm}^{\mathrm{r}}\right)$ nupG $\lambda^{-}$tonA & Gibco BRL \\
\hline \multicolumn{3}{|c|}{ 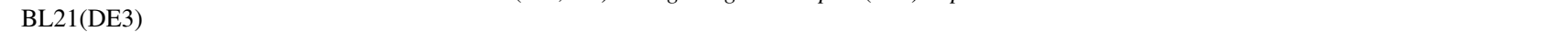 } \\
\hline pLysS & $\mathrm{F}^{-}$ompT hsdS $S_{B}\left(\mathrm{r}_{\mathrm{B}}^{-} \mathrm{m}_{\mathrm{B}}^{-}\right)$gal dcm (DE3) pLysS $\left(\mathrm{Cm}^{\mathrm{r}}\right)$ & Novagen \\
\hline \multicolumn{3}{|c|}{ Xanthomonas oryzae pv. oryzae } \\
\hline PXO99 & Philippine race 6 (PR6) strain, having AvrXa21 activity $\left(\mathrm{AvrXa21}{ }^{+}\right), \mathrm{Cp}^{\mathrm{r}}$ & Hopkins et al. 1992 \\
\hline DY89031 & Korean race 1 (KR1) strain, lacking AvrXa21 activity $($ AvrXa21- $), \mathrm{Cp}^{\mathrm{r}^{\mathrm{t}}}$ & S. H. Choi \\
\hline PXO99R & PXO99 $\operatorname{raxR}:: \mathrm{Km}, \mathrm{AvrXa21} 1^{+-}, \mathrm{Km}^{\mathrm{r}}$ & This study \\
\hline PXO99H & PXO99 raxH::Km, AvrXa21 ${ }^{+-}, \mathrm{Km}^{\mathrm{r}}$ & This study \\
\hline PXO99RH & PXO99 $\operatorname{raxR}:: \Omega$ raxH::Km, AvrXa21 ${ }^{+/-}, \mathrm{Km}^{\mathrm{r}}, \mathrm{Sm}^{\mathrm{r}}$ & This study \\
\hline PXO99-R* & PXO99 carrying pMLraxR, AvrXa21 ${ }^{+}, \mathrm{Gm}^{\mathrm{r}}$ & This study \\
\hline PXO99R-R* & PXO99R complemented with pMLraxR, AvrXa21+ $\mathrm{Km}^{\mathrm{r}}, \mathrm{Gm}^{\mathrm{r}}$ & This study \\
\hline PXO99R-ST* & PXO99R carrying pMLraxST, AvrXa21 $1^{+}, \mathrm{Km}^{\mathrm{r}}, \mathrm{Gm}^{\mathrm{r}}$ & This study \\
\hline PXO99H-H* & PXO99H complemented with pMLraxH, AvrXa21 ${ }^{+}, \mathrm{Km}^{\mathrm{r}}, \mathrm{Gm}^{\mathrm{r}}$ & This study \\
\hline PXO99H-R* & PXO99H carrying pMLraxR, AvrXa21 ${ }^{+}, \mathrm{Km}^{\mathrm{r}}, \mathrm{Gm}^{\mathrm{r}}$ & This study \\
\hline PXO99-a7 & PXO99 carrying plasmid pXO29-29, $\mathrm{Sm}^{\mathrm{r}}$ & This study \\
\hline PXO99-a10 & PXO99 carrying plasmid pXO5-15, $\mathrm{Sm}^{\mathrm{r}}$ & This study \\
\hline PXO99R-a7 & PXO99R carrying plasmid $\mathrm{pXO} 29-29, \mathrm{Km}^{\mathrm{r}}, \mathrm{Sm}^{\mathrm{r}}$ & This study \\
\hline PXO99R-a10 & PXO99R carrying plasmid pXO5-15, $\mathrm{Km}^{\mathrm{r}}, \mathrm{Sm}^{\mathrm{r}}$ & This study \\
\hline PXO99H-a7 & PXO99H carrying plasmid pXO29-29, $\mathrm{Km}^{\mathrm{r}}, \mathrm{Sm}^{\mathrm{r}}$ & This study \\
\hline PXO99H-a10 & PXO99H carrying plasmid $\mathrm{pXO} 5-15, \mathrm{Km}^{\mathrm{r}}, \mathrm{Sm}^{\mathrm{r}}$ & This study \\
\hline
\end{tabular}

\footnotetext{
${ }^{\mathrm{a}}$ AvrXa21 ${ }^{+}$causes short lesions (1 to $2 \mathrm{~cm}$ ) on Xa21 rice lines; AvrXa21-, causes long lesions (15 to $\left.25 \mathrm{~cm}\right)$ on Xa21 rice lines; AvrXa21 ${ }^{+/-}$, causes intermediate lesions $(5$ to $10 \mathrm{~cm}$ ) on Xa21 rice lines

${ }^{\mathrm{b}}$ National Crop Experiment Station, Rural Development Administration, Suwon, South Korea.
} 
showed lesions of similar lengths as those caused by DY89031, ranging from 3 to $5 \mathrm{~cm}$, and were significantly longer than lesions caused by the Xa21-avirulent strain PXO99 (data not shown). While lesions induced by DY89031 continued to extend up to 15 to $25 \mathrm{~cm}$ at 14 dai, lesions induced by the mutant strains extended to 5 to $10 \mathrm{~cm}$ (Fig. 2; Table 2). Lesions caused by wild-type PXO99 were significantly shorter, with averages from most experiments ranging from 1 to $2 \mathrm{~cm}$ (Fig. 2; Table 2).

To better quantify these results, we carried out in planta growth curve experiments. By 4 dai, PXO99R and PXO99H grew to higher levels in TP309-Xa21 as compared with PXO99 (Fig. 3A). Also by this time, the observed growth for the mutant strains was similar to that of DY89031 (Fig. 3A) and correlated with lesion length data (data not shown). At 12 dai, growth of PXO99R and PXO99H in TP309-Xa21 leaves was intermediate to growth of PXO99 and DY89031 (Fig. 3A). While differences in growth of PXO99 in TP309 vs. TP309-Xa21 started to appear 4 dai, PXO99R and PXO99H did not display differences in growth between these rice varieties until 6 dai. All strains were virulent on TP309 plants and grew to equally high levels in these plants (Fig. 3B). An additional growth curve experiment was carried out using the nontransgenic $O$. sativa subsp. indica cultivars IRBB21 and IR24 (carrying and lacking Xa21, respectively), and similar results for bacterial growth and lesion lengths were obtained (data not shown).

The above findings indicate that ORF13 and ORF14 are required for wild-type levels of AvrXa21 activity; therefore they were named $\operatorname{raxR}(\mathrm{RR})$ and $\operatorname{raxH}(\mathrm{HK})$, respectively. A PXO99 mutant strain impaired in both $\operatorname{raxR}$ and $\operatorname{raxH}$ (PXO99RH) also was created. Inoculation experiments showed that this strain did not display decreased AvrXa21 activity as compared with that of the single-mutant strains (Table 2).

\section{RaxR belongs to the OmpR family of RR and RaxH to the HPK subfamily of HK.}

Based on similarity searches, ORF predictions, and comparative analysis with similar two-component systems, it is likely that $\operatorname{raxR}$ and $\operatorname{raxH}$ are part of a single operon. BlastP revealed that RaxR and $\mathrm{RaxH}$ are highly similar to putative

Table 2. Summary of inoculation experiments of Xanthomonas oryzae pv. oryzae strains on TP309-Xa21 plants ${ }^{\mathrm{a}}$

\begin{tabular}{|c|c|c|c|c|c|c|c|c|c|}
\hline Experiment & PXO99 & PXO99R & РXО99H & PXO99RH & PXO99R-R* & PXO99R-ST & РХO99H-H* & PXO99H-R* & DY89031 \\
\hline 1 & $2.3 \pm 0.6$ & $5.6 \pm 0.6$ & $5.5 \pm 1.2$ & - & - & & & - & $19.6 \pm 0.5$ \\
\hline 2 & $1.9 \pm 0.9$ & $5.8 \pm 1.2$ & $5.9 \pm 1.9$ & - & - & & & - & $16.4 \pm 3.9$ \\
\hline 3 & $1.8 \pm 1.1$ & $6.4 \pm 1.9$ & - & - & $1.1 \pm 0.5$ & & & - & $16.0 \pm 2.8$ \\
\hline 4 & $2.1 \pm 1.4$ & $7.4 \pm 3.3$ & $6.7 \pm 2.1$ & $6.9 \pm 1.6$ & $2.1 \pm 1.6$ & & & & $25.7 \pm 2.9$ \\
\hline 5 & $0.9 \pm 0.4$ & $9.3 \pm 2.7$ & $10.0 \pm 3.1$ & $10.1 \pm 3.2$ & - & $1.9 \pm 1.7$ & - & $2.4 \pm 1.7$ & $15.4 \pm 2.9$ \\
\hline 6 & $3.2 \pm 0.9$ & $9.9 \pm 2.5$ & $9.7 \pm 3.2$ & $10.9 \pm 3.3$ & $3.0 \pm 1.2$ & $3.4 \pm 1.6$ & $3.6 \pm 2.3$ & $3.9 \pm 2.1$ & $26.0 \pm 3.8$ \\
\hline 7 & $1.9 \pm 0.8$ & - & $5.4 \pm 2.6$ & - & - & - & $2.1 \pm 1.8$ & - & $25.5 \pm 4.2$ \\
\hline
\end{tabular}

${ }^{a}$ Lesion lengths (average $\mathrm{cm} \pm$ standard deviation) were measured 14 days after inoculation (dai). In each experiment, four to eight leaves per plant (three to six plants per treatment) were inoculated. In planta growth curves were carried out in experiment 2 . TP309 plants (susceptible controls) were used in all experiments, and all strains were similarly virulent on this variety, with lesion lengths ranging between 15 and $25 \mathrm{~cm}$ among the different experiments.
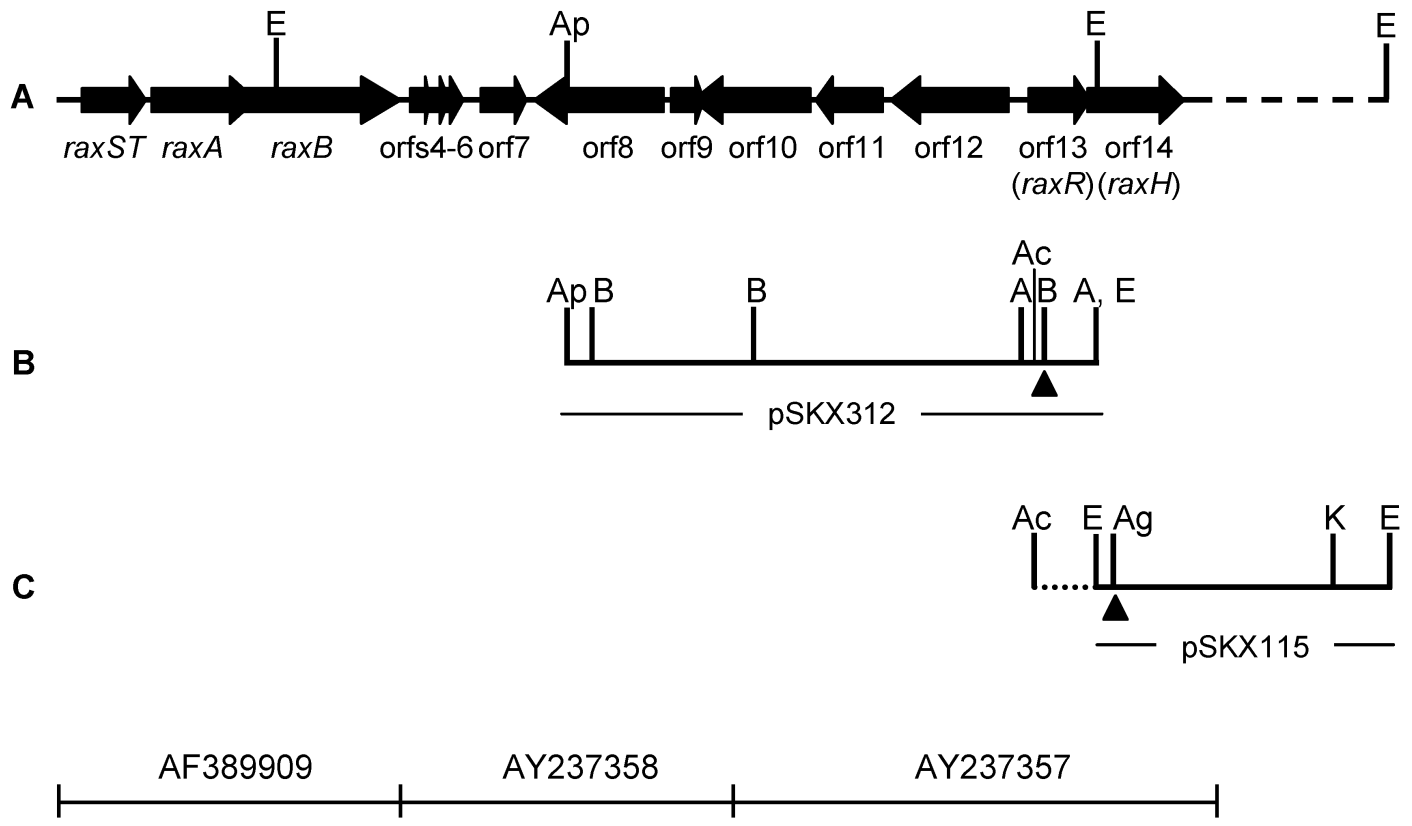

Fig. 1. Schematic representation of a 15.5-kb region from the Xanthomonas oryzae pv. oryzae chromosome, containing genes required for AvrXa21 activity. A, Sequences AF389909 and AY237358 (GenBank accession numbers) compose the 9-kb fragment from strain PXO99 in clone p10.78, which confers AvrXa21 activity to strain DY89031. AY237357 was sequenced from subclones of a PXO86 genomic library. Horizontal arrows indicate the predicted coding sequences of the various open reading frames. B, pSKX312 clone containing an ApaI-EcoRI 7,194-bp fragment from PXO86. C, pSKX115 clone containing an approximately 4-kb EcoRI fragment from PXO86. Dotted lines indicate the AccI-EcoRI 775-bp fragment from pSKX312 used to generate pUC115K+, for insertional mutagenesis of raxH. Triangles indicate sites of insertion of $\mathrm{Km}^{\mathrm{r}}$ or Sm$^{\mathrm{r}}$ cassettes for insertional mutagenesis. Relevant restriction sites: $\mathrm{E}=$ EcoRI, $\mathrm{Ap}=A p a \mathrm{I}, \mathrm{B}=B c l \mathrm{I}, \mathrm{A}=A p o \mathrm{I}, \mathrm{Ac}=A c c \mathrm{I}, \mathrm{Ag}=A g e \mathrm{I}, \mathrm{K}=K p n \mathrm{I}$. 
two-component elements of the related $X$. axonopodis pv. citri, and $X$. campestris pv. campestris RaxR shows 90 and $87 \%$ identity to NP_641557 (X. axonopodis pv. citri) and NP_636495 (X. campestris pv. campestris), respectively. RaxR also shows high similarity (63 to 66\%) to the putative RR NP_638454 and NP_636170 from $X$. campestris pv. campestris and to NP_643558 and NP_641186 from $X$. axonopodis pv. citri. Similarly, RaxH is 94 and $85 \%$ identical to NP_641558 from X. axonopodis pv. citri and NP_636496 from $\bar{X}$. campestris pv. campestris, respectively. It also shares similarity (46 to 49\%) with the putative HK NP_638453 and NP_636171 from $X$. campestris pv. campestris and to NP_643557 and NP_641187 from X. axonopodis pv. citri.

Among characterized two-component systems, the one giving the highest homology scores for the RaxH/RaxR system is the ColS/ColR system of the plant growth-promoting rhizobacterium Pseudomonas fluorescens, which is involved in bacterial root colonization (Dekkers et al. 1998); RaxR and ColR (CAA70931) share 69\% similarity and 51\% identity, whereas the levels of similarity and identity for RaxH and ColS (CAA70932) are 48 and 30\%, respectively. Other two-component systems showing similarity to RaxH/RaxR (48 to 53\% for RaxR; 45 to $50 \%$ for partial length of RaxH, mainly around the conserved $\mathrm{C}$-terminal region) are the Burkholderia pseudomallei IrlR/IrlS, which is involved in invasion of eukaryotic cells and heavy-metal resistance (Jones et al. 1997), and the Salmonella typhimurium BasR/BasS (or PmrA/PmrB), for which a role in virulence has been attributed (Roland et al. 1993).

Sequence analysis indicates that RaxR belongs to the wellstudied OmpR family of RR. For instance, RaxR shows $44 \%$ similarity with E. coli OmpR. PFAM analysis revealed the presence of typical $\mathrm{N}$-terminal $\mathrm{RR}$ receiver and $\mathrm{C}$-terminal transcriptional regulatory (effector) domains in RaxR. RaxH has typical histidine kinase A (dimerization and phosphoacceptor) and HATPase_c (ATP-binding kinase) domains in the C-terminus. In addition, a HAMP domain (histidine kinases, adenylyl cyclases, methyl binding proteins and phosphatases) with unknown function is found in RaxH. A SMART search also revealed the presence of two transmembrane segments, suggesting the presumed $\mathrm{RaxH}$ is a typical transmembrane HK. Based on multiple sequence alignment of 348 kinase domains, Grebe and Stock (1999) designated 11 HK subfamilies, named $\mathrm{HPK}_{1}$ to $\mathrm{HPK}_{11}$. According to homology analysis, RaxH belongs to the $\mathrm{HPK}_{2}$ subfamily that also contains ColS and EnvZ, the cognitive HK of ColR and OmpR, respectively.

\section{PXO99R and PXO99H are complemented}

\section{to wild-type levels of AvrXa21 activity}

by pML122 overexpressing $\operatorname{rax} R$ and $\operatorname{raxH}$, respectively.

The $\operatorname{rax} R$ and raxH coding sequences from PXO99 were cloned into the expression vector pML122, generating pMLraxR and pMLraxH, respectively. Sequencing of these genes from PXO99 revealed 100\% identity with the corresponding genes from PXO86. PXO99R ( raxR mutant) carrying pMLraxR displayed lesion lengths similar to wild-type PXO99 in TP309-Xa21 leaves. Similarly, PXO99H ( $r a x H$ mutant) was complemented for AvrXa21 activity by pMLraxH (Table 2).

Interestingly, PXO99H carrying pMLraxR was also shown to have an increased AvrXa21 activity in comparison with PXO99H, as observed by the reduced lesion lengths in TP309Xa21 leaves induced by this strain (Table 2). Complementation of the $\operatorname{raxH}$ mutation by pMLraxR not only confirms RaxR overexpression in planta but also indicates that at least part of the overexpressed RR protein is activated in the absence of the HK.
The RaxH/RaxR system does not affect AvrXa7 and AvrXa10 activities.

The $X$. oryzae pv. oryzae-Xa21 interaction is unique in that it requires a functional bacterial type I secretion system and likely involves extracellular recognition of AvrXa21 by the $X a 21$ gene product. Therefore, we investigated whether the $\mathrm{RaxH} / \mathrm{RaxR}$ system is relevant for activity of other $X$. oryzae pv. oryzae avr genes, avrXa7 and avrXa10. These genes are presumed to encode intracellular effectors delivered into the plant cell via a type III secretion system (Yang et al. 2000; Zhu et al. 2000). Since Xa7 and Xa10 rice lines are susceptible to PXO99, plasmids pXO5-15 and pXO29-29 expressing avrXa10 and avrXa7 from strain PXO86 (Hopkins et al. 1992), respectively, were introduced into wild-type PXO99 and the mutant strains PXO99R and PXO99H.

As expected, PXO99, PXO99R, and PXO99H were virulent on Xa7 and Xa10 lines (Fig. 4), and all strains were virulent on IR24 plants (susceptible control; data not shown). PXO99R and PXO99H carrying avrXa7 or avrXal0 caused lesions with lengths similar to those caused by PXO99 expressing the corresponding $a v r$ gene in Xa7 or Xa10 plants (Fig. 4). In other words, the RaxH/RaxR system has no effect on AvrXa7 and AvrXa10 activities.

\section{Expression and purification}

of recombinant RaxR from $E$. coli.

The raxR coding sequence from PXO99 was cloned into pET-15b, to create recombinant RaxR fused to a histidine tag (His $6 \times \operatorname{tag}$ ) in its $\mathrm{N}$-terminus. The resulting vector, pETraxR, was transformed into $E$. coli BL21(DE3)pLysS, in which overexpression of recombinant His-RaxR protein was induced by the addition of isopropyl- $\beta$-D-thiogalactoside (IPTG). The calculated molecular mass for the recombinant His-RaxR is $2.888314 \mathrm{kDa}$, thus coinciding with the mobility observed in sodium dodecyl sulfate-polyacrylamide gel electrophoresis

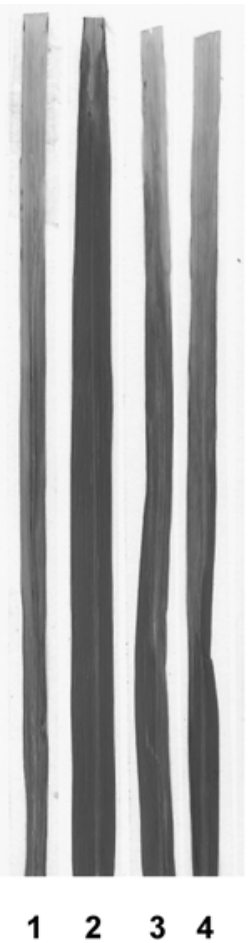

Fig. 2. Lesions on TP309-Xa21 leaves inoculated with the following Xanthomonas oryzae pv. oryzae strains. $1=$ DY89031, $2=$ PXO99, $3=$ PXO99R (raxR mutant), and $4=$ PXO99H ( raxH mutant). Shown 14 days after inoculation. 
(SDS-PAGE) (data not shown) and in Western blots using antiHis $6 \times$ monoclonal antibodies (Fig. 5A). The double-band pattern following induction with IPTG is frequently observed for highly overexpressed recombinant proteins and seems to be the result of partial premature translation termination or protein degradation (The QIAexpressionist, a handbook for highlevel expression and purification of 6X His-tagged proteins, Qiagen, Valencia, CA, U.S.A.).

For production of anti-RaxR antibodies, the recombinant protein was purified under denaturative conditions, using $\mathrm{Ni}^{2+}$ NTA columns according to manufacturer's procedures (The QIAexpressionist; data not shown).

\section{$X$. oryzae pv. oryzae expresses wild-type $\operatorname{RaxR}$ in culture.}

An XbaI-HindIII fragment from pETraxR containing the His-RaxR coding sequence was cloned into pML122 to generate pMLraxR (the same construct was used for complementation of PXO99R, as previously described). pMLraxR was introduced into PXO99, generating PXO99-R*. Overexpression of His-RaxR in this strain was clearly observed by comparing its protein profiles with those of wild-type PXO99 and PXO99R (raxR mutant strain) grown in different media (nutrient broth [NB], M9 minimal medium, and peptone sucrose) in SDS-PAGE (data not shown). These results were confirmed by Western blot analyses using anti-His $6 \times$ and anti-RaxR antibodies (Fig. 5). Note that, for detection with anti-RaxR antibodies (Fig. 5B), the overexpressed signal observed in PXO99-R* extracts was obtained from a loaded sample containing significantly less total protein as compared with that in PXO99 and PXO99R samples. HisRaxR was detected at a similar intensity in extracts of M9 minimal medium- and peptone sucrose-grown PXO99-R* cells (data not shown).

Western blots with anti-RaxR antibodies led to the detection of a band with the expected size, the same as that of wild-type RaxR (2.685682 kDa) in protein extracts of NB-grown PXO99 cells (Fig. 5B). Similar bands were also detected in protein extracts of PXO99 grown in M9 minimal medium and peptone sucrose broth, although with a lower intensity than in NB (data not shown). The results discussed above suggest that $\operatorname{rax} R$ is constitutively expressed in PXO99 cultures.

To verify the above results, we created a $\operatorname{rax} R$ promoterreporter construct using the promoterless-gfp (green fluorescent protein)-containing vector pPROBE-NT, for which efficiency as a promoter-probe vector was recently demonstrated for other plant pathogens, such as Erwinia herbicola and Pseudomonas syringae (Miller et al. 2000). PXO99 cells carrying pPROBE-NT-pR1 (containing a 381-bp fragment upstream of the raxR coding sequence fused to promoterless$g f p$ ) were grown for 24 and $48 \mathrm{~h}$ in NB (supplied with kanamycin $[\mathrm{Km}]$ ) and compared for GFP expression with wildtype PXO99 as well as with PXO99 carrying "empty" pPROBE-NT. A pPROBE-NT construct, in which a DNA region located within the $\operatorname{raxR}$ coding sequence was fused to the promoterless- $g f p$, was used as an additional negative control. PXO99 cells carrying pPROBE-NT-pR1 gave significantly higher fluorescence values after 24 and $48 \mathrm{~h}$ of growth, as compared with the other strains, which did not show significant differences among each other (data not shown). Observation of bacterial cultures using a confocal microscope correlated with these results, since fluorescence was only observed in PXO99 cells carrying pPROBE-NTpR1. These findings support Western blot results showing that RaxR is expressed in culture.

PXO99 carrying the above constructs were also used to inoculate 3- to 4-cm pieces of TP309-Xa21 leaves. The leaves were inoculated by infiltration of bacterial suspensions $\left(10^{9}\right.$ $\mathrm{CFU}$ per $\mathrm{ml}$ of water) through the main vein and were incubated at $30^{\circ} \mathrm{C}$ for 5 days in petri dishes containing a layer of wet filter paper. In bacteria grown in culture, only cells carrying pPROBE-NT-pR1 were fluorescent (data not shown), thus supporting results from inoculation experiments in which the $\mathrm{RaxH} / \mathrm{RaxR}$ system is expressed in planta.

\section{The $\operatorname{rax} R$ mutation affects expression of the $\operatorname{raxSTAB}$ promoter in PXO99.}

Due to the chromosomal proximity of $\operatorname{raxSTAB}$ and $\operatorname{rax} R H$, as well as the apparent uniqueness of the $\operatorname{rax} S T A B$ region in $X$.
A

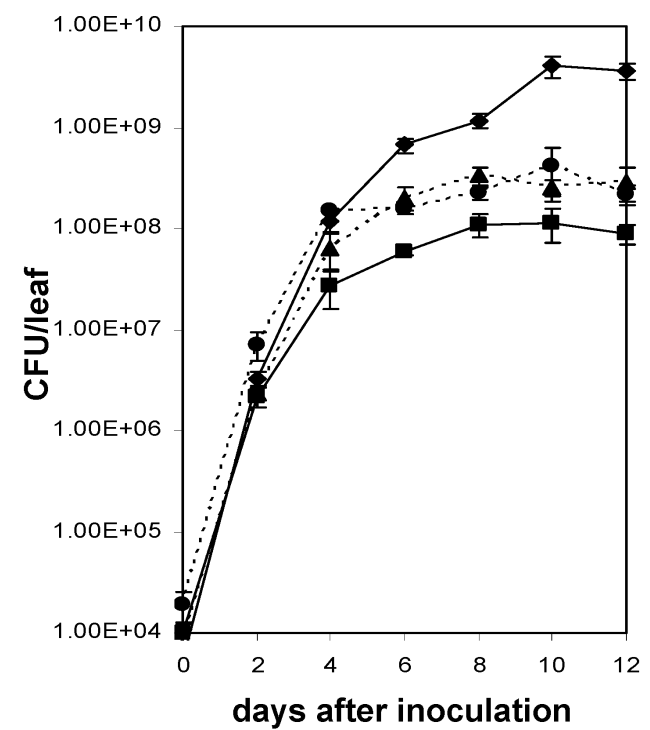

B

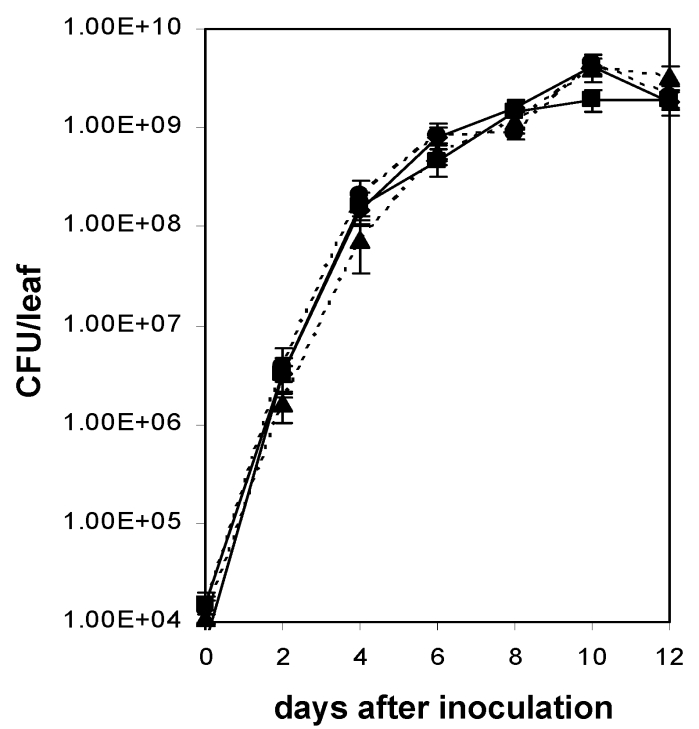

Fig. 3. Bacterial concentration (CFU/leaf) of different Xanthomonas oryzae pv. oryzae strains in A, TP309-Xa21- and B, TP309-inoculated leaves. PXO99 ( $\boldsymbol{\square}$, solid lines), PXO99R ( $\bullet$, dashed lines), PXO99H ( $\boldsymbol{\Delta}$, dashed lines), and DY89031 ( $\bullet$, solid lines). Bacteria were extracted from leaves every two days, and bacterial concentration was determined by serial dilution counts. Each value represents averages \pm standard deviation of three sampled leaves per treatment. 
oryzae pv. oryzae (da Silva et al. 2004), we tested whether the $\operatorname{rax} S T A B$ operon is a target for $\mathrm{RaxH} / \mathrm{RaxR}$ regulation. Preliminary observations indicated that expression of the $\operatorname{raxSTAB}$ operon in culture occurs at very low levels. Indeed, we were not able to detect $\operatorname{rax} S T, \operatorname{rax} A$, or $\operatorname{rax} B$ RNA in Northern blot experiments in either PXO99R or PXO99 (data not shown). This could be due to either low expression of these genes, RNA instability, or both, known to be important limiting factors for detection of bacterial RNA.

As an alternative to Northern blot analysis, a 309-bp DNA fragment upstream of the $\operatorname{rax} S T$ coding sequence, presumably containing the $\operatorname{raxSTAB}$ promoter (named pST), was cloned into pPROBE-AT upstream of the promoterless- $g f p$ for promoter-reporter studies. The resulting plasmid, pPROBE-AT-pST was electroporated into PXO99 and PXO99R cells. pPROBE-AT-pNm, carrying a pML122 fragment containing the $\mathrm{pNm}$ promoter (from nptII; constitutively expressed in $X$. oryzae pv. oryzae) was also introduced into the wild-type and $\operatorname{raxR}$ mutant strains, to allow determination of relative activity of the pST promoter. As a negative control, pPROBE-AT (carrying promoterless $g f p$ ) was also introduced in these strains. Similar values of fluorescence were obtained when comparing PXO99 and PXO99R for the pNm- $g f p$ fusion and pPROBE-AT for the negative control. No differences were observed in growth rate between the different strains (data not shown). Figure 6 shows that the $\operatorname{rax} R$ mutation in PX099R clearly suppresses the activity of pST. Interestingly, in PXO99R, pPROBE-AT-pST gave higher fluorescence values than pPROBE-AT (data not shown), sug-

\section{IRBB7}

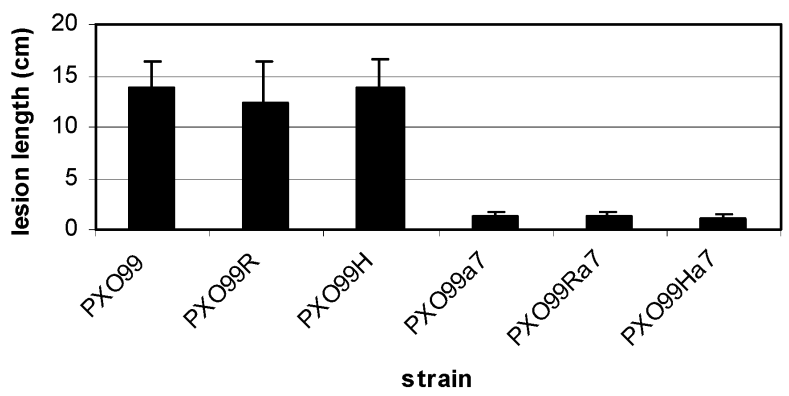

IRBB10

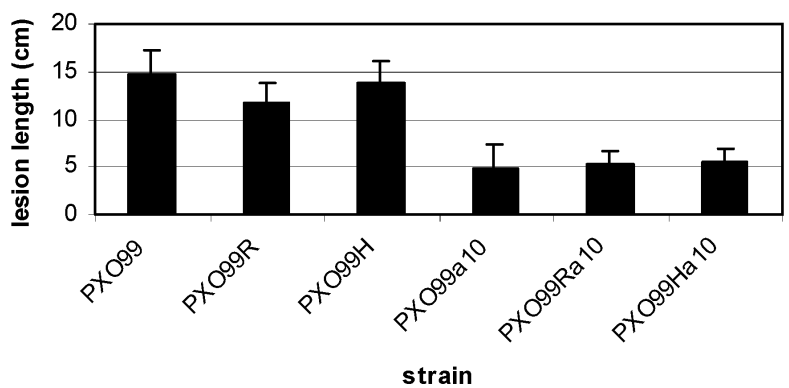

Fig. 4. Lesion lengths in leaves of IRBB7 and IRBB10 rice plants inoculated with strains PXO99, PXO99R, and PXO99H, and the same strains expressing either avrXa7 (a7) or avrXa10 (a10), 14 days after inoculation. Three or four plants (four to six leaves per plant) were inoculated with each strain. Bars represent average \pm standard deviation from one of two independent experiments with comparable results. No differences in lesion lengths were found among the strains in IRBB24 plants (data not shown). gesting the occurrence of residual pST activity in the background of the $\operatorname{rax} R$ mutation.

Inoculation experiments showed that PXO99R overexpressing raxST (cloned into pML122) induced shorter lesions in TP309-Xa21 leaves as compared with PXO99R (Table 2). This finding is in agreement with the results from promoter expression analysis and further supports that the $\operatorname{rax} S T A B$ operon is likely a target of $\mathrm{RaxH} / \mathrm{RaxR}$ regulation.

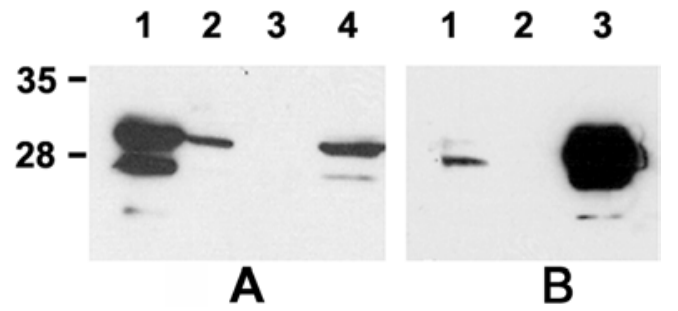

Fig. 5. Expression of RaxR in Escherichia coli and in Xanthomonas oryzae pv. oryzae. A, Western blot analysis of various $X$. oryzae pv. oryzae strains, and E. coli BL21(DE3)pLysS carrying pETraxR. X. oryzae pv. oryzae strains were grown in nutrient broth $(\mathrm{NB})$ (with gentimycin for PXO99 carrying pMLraxR) for $24 \mathrm{~h}$. Detection with anti-His $6 \times$ monoclonal antibodies (1:5,000; Sigma) and horseradish peroxidaseanti-mouse IgG (1:10,000; Jackson ImmunoResearch Laboratories) as primary and secondary antibodies, respectively. Lane 1, BL21-pETraxR, 1 mM IPTG, lane 2, BL21-pETraxR, no IPTG, lane 3, PXO99, and lane 4, PXO99-R* (PXO99 carrying pMLraxR). Membranes were exposed for $15 \mathrm{~s}$ to an $\mathrm{X}$-ray film. B, Detection of RaxR from various $X$. oryzae pv. oryzae strains grown in nutrient broth for $24 \mathrm{~h}$, using anti-RaxR polyclonal antibodies $(1: 3,000)$ and HRP-anti-rabbit IgG (1:10,000, Cappel Laboratories) as primary and secondary antibodies, respectively. Lane 1, PXO99, lane 2, PXO99R (raxR mutant), and lane 3, PXO99-R*. For PXO99 and PXO99R extracts, $15 \mu$ were loaded, and for PXO99-R*, $3 \mu \mathrm{l}$ were loaded. Membranes were exposed for $1 \mathrm{~min}$ to an X-ray film.

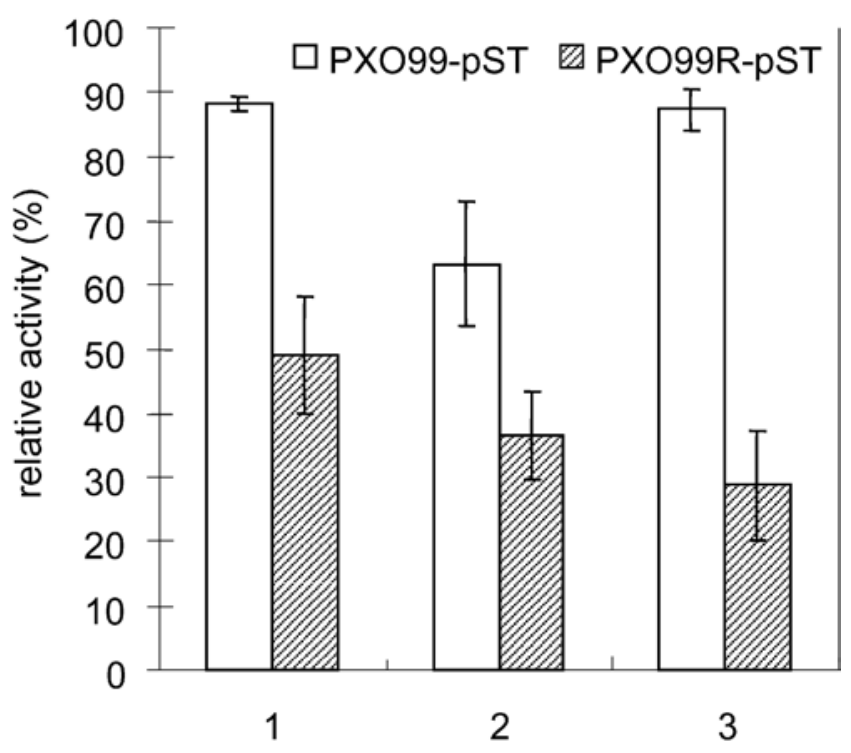

Fig. 6. Relative activity of the $\operatorname{rax} S T A B$ promoter (pST) in wild-type (PXO99) and raxR mutant (PXO99R) strains. Cells carrying pPROBEAT-pST were grown in nutrient broth with ampicillin for $24 \mathrm{~h}$ to the middle exponential phase. After two washings with PBS (20 mM $\mathrm{NaHPO}_{4}, 150 \mathrm{mM} \mathrm{NaCl}, \mathrm{pH} 8.0$ ), cells were resuspended with the same buffer to an optical density at $600 \mathrm{~nm}=1.0$. Fluorescence was measured at 490- and 510-nm excitation and emission wavelengths, respectively. pST relative activities in PXO99 and PXO99R were calculated relative to PXO99 and PXO99R cells expressing pPROBE-AT-pNm, respectively, $(\mathrm{pNm}=100 \%)$. Results from three independent experiments are shown. In each experiment, data represent average \pm standard deviation of three independent replicates (cultures). 


\section{DISCUSSION}

The rice $\mathrm{Xa} 21$ resistance gene encodes a RK with a presumed extracellular domain that is responsible for race-specific recognition of X. oryzae pv. oryzae (Song et al. 1995). Recent characterization of six $X$. oryzae pv. oryzae rax genes indicate that type I secretion $(\operatorname{rax} A, \operatorname{rax} B$, and $\operatorname{rax} C)$ and sulfation $(\operatorname{rax} S T$, $\operatorname{rax} P$, and $\operatorname{rax} Q$ ) are required for Xa21-mediated recognition of $X$. oryzae pv. oryzae (da Silva et al. 2004; Shen et al. 2002).

In the present study, two ORF encoding proteins with similarity to RR and HK of the OmpR/EnvZ class of bacterial twocomponent regulatory systems were identified downstream of the $\operatorname{rax} S T A B$ genomic region. Because several two-component regulatory systems regulate virulence and pathogenicity (Grebe and Stock 1999; Stock et al. 2000; West and Stock 2001), we investigated whether this presumed two-component system is involved in the $X$. oryzae pv. oryzae-Xa21 interaction.

Null mutant strains for the RR and HK ORF were generated by insertional inactivation in strain PXO99 carrying AvrXa21 activity. Inoculation experiments showed that these ORF are required for wild-type levels of AvrXa21 activity, and the genes were consequently named $\operatorname{raxR}$ and $\operatorname{raxH}$. Lesion length analysis and in planta growth curve experiments showed that the PXO99 $\operatorname{raxR}$ and $\operatorname{raxH}$ mutant strains possess an intermediate phenotype between wild-type strains PXO99 and DY89031, the latter lacking AvrXa21 activity. Also, both mutant strains induce shorter lesions in Xa21 leaves as compared with those of some of the other PXO99 rax mutants, such as the $\operatorname{raxST}$ knockout strain (data not shown). A double-mutant strain impaired in both $\operatorname{raxR}$ and $\mathrm{raxH}$ did not display a further decrease in AvrXa21 activity. These results suggest that the raxH and raxR mutant strains do elicit a defense response in $\mathrm{Xa} 21$ plants but that this response is delayed or weaker, or both, as compared with that in wild-type PXO99.

A possible explanation for the intermediate phenotype caused by inactivation of the RaxH/RaxR system may be that other factors, including additional two-component systems, are involved in regulation of AvrXa21 activity and that inactivation of one of these systems is not sufficient for its complete inhibition. As an example of redundant two-component regulation, two two-component regulatory systems (named System 1 and System 2) that regulate virulence of the gramnegative human pathogen Vibrio cholerae were recently identified (Miller et al. 2002). Moreover, using the Vibrio harveyi luciferase (lux) operon as a heterologous reporter, Miller and associates (2002) showed that a $V$. cholerae double mutant, inactivated in both System 1 and System 2, still retains density-dependent lux expression, thus suggesting the involvement of at least one additional sensory circuit. Indeed, sequencing of the genomes of $X$. axonopodis pv. citri and $X$. campestris pv. campestris revealed the presence of more than 30 two-component regulatory systems in these species, with one being identical and two highly similar (in each species) to the $X$. oryzae pv. oryzae $\mathrm{RaxH/RaxR}$ system. It is not yet known if the $X$. oryzae pv. oryzae genome encodes two-component systems similar to $\mathrm{RaxH} / \mathrm{RaxR}$, as the $X$. oryzae $\mathrm{pv}$. oryzae genome has not yet been published. If present in $X$. oryzae pv. oryzae, these additional systems could also play a role in AvrXa21 regulation. In addition, we cannot discount the possibility that the intermediate phenotype is due to lowlevel constitutive expression of rax genes regulated by the $\mathrm{RaxH} / \mathrm{RaxR}$ system.

In the absence of the HK or of the required environmental signal, some RR are able to catalyze phosphoryl transfer from small molecules such as acetyl phosphate; moreover, this kind of RR phosphorylation seems to be more biologically relevant than phosphoryl transfer from noncognitive
HK (Lukat et al. 1992; McCleary et al. 1993). Inoculation experiments indicated that the $\operatorname{raxH}$ mutation is complemented by overexpression of $\operatorname{rax} R$. This finding has an important implication for future studies on gene regulation by the RaxH/RaxR system, since PXO99 cells overexpressing $\operatorname{rax} R$ could be used for expression studies in the absence of the RaxH-activating environmental signal (which is still unknown). Recently, Noël and associates (2001) compared cDNA-AFLP profiles of a $X$. campestris pv. vesicatoria wildtype strain and a strain expressing a mutated form of HrpG (a RR that belongs to the OmpR family) that leads to constitutive expression of $h r p$ genes in normally noninducing medium. Using this approach, $30 \mathrm{hrpG}$-induced and five $\mathrm{hrpG}$ repressed cDNA fragments were successfully detected.

An important question regarding the role of the RaxH/RaxR system in regulation of avirulence is if this two-component system is relevant for expression of other $X$. oryzae pv. oryzae $a v r$ genes. The present study showed that inactivation of $\operatorname{raxR}$ or raxH does not affect AvrXa7 and AvrXa10 activities. In contrast to avrXa7 and avrXal0 that encode typical Avr effectors, which are likely delivered by a type III secretion system and recognized by plant intracellular receptors (Yang et al. 2000; Zhu et al. 2000), the recognition of AvrXa21 is predicted to occur in the extracellular environment. The fact that the RaxH/RaxR system affects AvrXa21 but not AvrXa7 and AvrXa10 activities emphasizes the unique aspects of the $X$. oryzae pv. oryzae-Xa21 system within the context of $a v r-R$ gene interactions.

The investigation into how the RaxH/RaxR system controls AvrXa21 activity is in its infancy. However in this study, we show evidence from promoter-reporter studies and inoculation experiments suggesting that the $\operatorname{rax} S T A B$ locus is a target for RaxH/RaxR regulation. Moreover, the residual pST activity observed in the background of the $\operatorname{rax} R$ mutation is in agreement with the intermediate AvrXa21 activity observed for the $\operatorname{raxR} / \mathrm{raxH}$ mutant strains in inoculation experiments. Whether RaxR up-regulates the $\operatorname{raxSTAB}$ locus directly or through an intermediate transcription factor and whether RaxR is involved in regulation of other rax genes are questions that remain to be answered. It is particularly intriguing that both $X$. campestris pv. campestris and $X$. axonopodis pv. citri possess orthologs for $\operatorname{raxR}$ and $\operatorname{raxH}$ (and a high level of identity with the sequenced approximately 15.5 $\mathrm{kb}$ genomic region from $X$. oryzae pv. oryzae) but not for the $\operatorname{rax} S T A B$ locus. This observation suggests that the $\mathrm{RaxH} / \mathrm{RaxR}$ system may be involved in regulation of a broad spectrum of genes, not all necessarily related to AvrXa21 activity. Identification of additional $\mathrm{RaxH} / \mathrm{RaxR}$ targets in $X$. oryzae pv. oryzae as well as in the related xanthomonads is, therefore, of interest.

To date, we have isolated eight $X$. oryzae pv. oryzae genes required for AvrXa21 activity. These genes fall into three classes: type I secretion, sulfur metabolism, and two-component regulation. Further characterization of the interaction among the encoded products of these genes and identification of new AvrXa21 determinants will contribute to the understanding of the $X$. oryzae pv. oryzae-Xa21 interaction as well as possible isolation of AvrXa21 itself. The unique aspects of the $X$. oryzae pv. oryzae-Xa21 system suggest that AvrXa21 may represent an entirely new class of bacterial signaling molecules.

\section{MATERIALS AND METHODS}

Bacterial strains, plasmids, and growth conditions.

Bacterial strains and plasmids used in this work are described in Tables 1 and 3, respectively. X. oryzae pv. oryzae strains were grown in peptone sucrose media (Tsuchiya et al. 
1982), NB (Difco Laboratories, Detroit), or M9 minimal medium at $28^{\circ} \mathrm{C}$. For solid media, $16 \mathrm{~g}$ of agar per liter was added. E. coli strains were cultured in Luria-Bertani medium at $37^{\circ} \mathrm{C}$ or as otherwise stated. Antibiotics used in this study were: $\mathrm{Km}, 50 \mu \mathrm{g} \mathrm{ml}^{-1}$; streptomyicin $(\mathrm{Sm}), 50 \mu \mathrm{g} \mathrm{ml}^{-1}$; ampicillin (Ap), $100 \mu \mathrm{g} \mathrm{ml}^{-1}$; cephalexin, $20 \mu \mathrm{g} \mathrm{ml}^{-1}$; chloramphenicol, $34 \mu \mathrm{g} \mathrm{ml}^{-1}$; and gentamicin $(\mathrm{Gm}), 30 \mu \mathrm{g} \mathrm{ml}^{-1}$ for $E$. coli and $15 \mu \mathrm{g} \mathrm{ml}{ }^{-1}$ for $X$. oryzae pv. oryzae.

\section{Molecular techniques.}

Plasmid DNA preparations, restriction enzyme digestions, and other routine DNA manipulations were performed using standard procedures (Sambrook et al. 1989). Genomic DNA from $X$. oryzae pv. oryzae was prepared according to Ausubel and associates (1994). For Southern blot hybridization, $\left[{ }^{32} \mathrm{P}\right]-$ dCTP (NEN Life Science Products, Boston) was used to label DNA probes with a random labeling kit (Amersham Life Science, Arlington Height, IL, U.S.A.). DNA sequencing of DNA fragments cloned in pUC18 or pBluescript was performed by the dideoxy chain termination method, using an automated sequencer (Model 400 I; Li-Cor, Lincoln, NE, U.S.A.) (Sanger et al. 1977). Standard M13 and M13R primers were used for sequencing of fragment 5' and 3' ends, and internal gaps were sequenced by polymerase chain reaction (PCR)-walking with syn- thesized primers (MWG Biotech Inc., High Point, NC, U.S.A.). PCR was performed with Taq polymerase (Promega Corp., Madison, WI, U.S.A.), using a programmable thermal controller (MJ Research Inc., Watertown, MS, U.S.A.) according to standard conditions. DNA fragments were purified from agarose gels, using the Zymoclean gel DNA recovery kit (Zymo Research, Orange, CA, U.S.A.). Restriction enzymes and T4 DNA ligase were from New England Biolabs, Inc. (Beverly, MA, U.S.A.). Bacterial transformations were carried out with a BRL electroporator (Life Technologies Inc., Gaithersburg, MD, U.S.A.). DNA sequences were analyzed and assembled using Sequencher (Gene Codes Corp., Ann Arbor, MI, U.S.A.). DNA and protein homology analysis and searches for ORF were performed with the Blast algorithm (Altschul et al. 1997) and ORF Finder, respectively, through the National Center for Biotechnology Information. Domain analyses were carried out using PFAM and SMART software. Multiple alignments were carried out using ClustalW (Thompson et al. 1994).

\section{Construction of $\operatorname{raxR}$ and $\operatorname{raxH}$ null mutants by insertional mutagenesis.}

To generate a PXO99 raxR mutant (PXO99R), an ApoI 1,021-bp fragment from pSKX312 (Fig. 1) was subcloned into pUC18, and a $\mathrm{Km}$ resistance cassette was inserted into the

Table 3. Plasmids used in this study

\begin{tabular}{|c|c|c|}
\hline Plasmid & Relevant characteristics & Source or reference \\
\hline pUC18 & pMB1 ori, $\mathrm{Ap}^{\mathrm{r}}$ & Invitrogen Corp., Carlsbad, CA, U.S.A. \\
\hline pBluescript II SK & Phagemid, $\mathrm{pUC}$ derivative, $\mathrm{Ap}^{\mathrm{r}}$ & Strategene, La Jolla, Ca, U.S.A. \\
\hline pUC-4K & pUC4 derivative (pMB1 ori, Ap ${ }^{\mathrm{r}}$ ), containing a $\mathrm{Km}^{\mathrm{r}}$ cassette (from Tn903) & $\begin{array}{l}\text { Amersham Pharmacia Biotech, } \\
\text { Piscataway, NJ, U.S.A. }\end{array}$ \\
\hline $\mathrm{pHP} 45 \Omega$ & pBR322 ori, $\mathrm{Ap}^{\mathrm{r}}$, containing the $\Omega$ cassette $\left(\mathrm{Sm}^{\mathrm{r}}\right)$ from R100.1 & Prentki and Krisch 1984 \\
\hline pCR2.1 & ColE1 ori, F1 ori, $\mathrm{Ap}^{\mathrm{r}}, \mathrm{Km}^{\mathrm{r}}$ & Invitrogen Corp. \\
\hline pET-15b & pBR322 ori, Ap ${ }^{\mathrm{r}}$, T7 promoter, lac operator, His $6 \times$ tag coding sequence & Novagen, Madison, WI, U.S.A. \\
\hline pML122 & OriV, OriT, $\mathrm{Gm}^{\mathrm{r}}, p \mathrm{Nm}(n p t \mathrm{II})$, broad-host range expression vector & Labes et al. 1990 \\
\hline pPROBE-NT & pBBR1-derived vector containing a promoterless $g f p$ for promoter-reporter studies, $\mathrm{Km}^{\mathrm{r}}$ & Miller et al. 2000 \\
\hline pPROBE-AT & pBBR1-derived vector containing a promoterless $g f p$ for promoter-reporter studies, $\mathrm{Ap}^{\mathrm{r}}$ & Miller et al. 2000 \\
\hline p10.78 & $\begin{array}{l}\text { pUFR027 (DeFeyter et al. 1990) clone containing a Sau3A I 9-kb-fragment from } \\
\text { PXO99 conferring AvrXa21 activity to Xanthomonas oryzae pv. oryzae DY89031 }\end{array}$ & da Silva et al. 2004 \\
\hline PHMX7-10 & $\begin{array}{l}\text { Cosmid clone of PXO86 (Philippine race 2) containing a Sau3A I approximately 25-kb } \\
\text { fragment hybridizing with the PXO99 9-kb fragment from p10.78 }\end{array}$ & This study \\
\hline pSKX312 & $\begin{array}{l}\text { pBluescript containing an ApaI-EcoRI 7,194-bp genomic fragment from PXO86, } \\
\text { containing } \operatorname{raxR} \text { and partial raxH ORFs }\end{array}$ & This study \\
\hline pSKX115 & $\begin{array}{l}\text { pBluescript containing an EcoRI genomic fragment of about } 4 \mathrm{~kb} \text { from PXO86, } \\
\text { containing partial raxH ORF }\end{array}$ & This study \\
\hline pUCA1K & $\begin{array}{l}\text { pUC18 carrying an ApoI 1,021-bp fragment from pSKX312 containing part of the raxR } \\
\text { ORF, disrupted by a Km }{ }^{\mathrm{r}} \text { cassette }\end{array}$ & This study \\
\hline pUC115K+ & $\begin{array}{l}\text { pUC18 containing an } A c c \mathrm{I}-K p n \mathrm{I} \sim 4 \mathrm{~kb} \text { genomic region from PXO86 with the raxH ORF } \\
\text { disrupted by a Km }{ }^{\mathrm{r}} \text { cassette }\end{array}$ & This study \\
\hline pUCA1S & $\begin{array}{l}\text { pUC18 carrying an ApoI 1,021-bp fragment from pSKX312 containing part of the } \operatorname{raxR} \\
\text { ORF, disrupted by a Sm }{ }^{\mathrm{r}} \text { cassette }\end{array}$ & This study \\
\hline pCRraxR & pCR2.1 containing the PXO99 $\operatorname{rax} R$ coding sequence & This study \\
\hline pETraxR & $\begin{array}{l}\text { pET- } 15 \mathrm{~b} \text { containing the } \operatorname{raxR} \text { coding sequence cloned into the } N d e \mathrm{I}-\mathrm{BamHI} \text { sites, fused } \\
\text { to a His } 6 \times \text { tag in the N-terminus }\end{array}$ & This study \\
\hline pMLraxR & $\begin{array}{l}\text { pML122 carrying an XbaI-HindIII fragment from pETraxR for expression of His-RaxR } \\
\text { in X. oryzae pv. oryzae }\end{array}$ & This study \\
\hline pUCraxH & pUC18 containing the PXO99 $\mathrm{raxH}$ coding sequence & This study \\
\hline pETraxH & 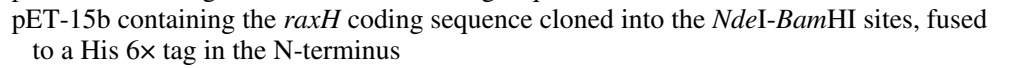 & This study \\
\hline pMLraxH & $\begin{array}{l}\text { pML122 carrying an XbaI-HindIII fragment from pETraxH for expression of His-RaxH } \\
\text { in X. oryzae pv. oryzae }\end{array}$ & This study \\
\hline pMLraxST & pML122 carrying raxST for expression in X. oryzae pv. oryzae & $\begin{array}{l}\text { C. Dardick, University of California- } \\
\text { Davis, U.S.A. }\end{array}$ \\
\hline pXO5-15 & pHM1 clone from PXO86 that contains avrXa10 & Hopkins et al. 1992 \\
\hline pXO29-29 & pHM1 clone from PXO86 that contains avrXa7 & Hopkins et al. 1992 \\
\hline pPROBE-NT-pR1 & $\begin{array}{l}\text { pPROBE-NT carrying a PXO99 approsimately } 380 \text {-bp fragment upstream of the } \operatorname{rax} R \\
\text { coding sequence fused to promoterless- } g f p, \mathrm{Km}^{\mathrm{r}}\end{array}$ & This study \\
\hline pPROBE-AT-pST & $\begin{array}{l}\text { pPROBE-AT carrying a PXO99 309-bp fragment upstream of the } \operatorname{raxST} \text { coding } \\
\text { sequence fused to promoterless- } g f p, \mathrm{Ap}^{\mathrm{r}}\end{array}$ & This study \\
\hline pPROBE-AT-pNm & $\begin{array}{l}\text { pPROBE-AT carrying a 212-bp fragment from pML122 that contains the } \mathrm{pNm} \text { promoter } \\
\text { (nptII) fused to promoterless- } g f p, \mathrm{Ap}^{\mathrm{r}}\end{array}$ & This study \\
\hline
\end{tabular}


$B c l$ s site of the above fragment to generate construct pUCA1K. For creation of a PXO99 mutant impaired in raxH (PXO99H), the EcoRI fragment from pSKX115 (Fig. 1) was subcloned into pUC18, and a $\mathrm{Km}^{\mathrm{r}}$ cassette was inserted into the AgeI site of the above fragment to generate construct pUC115K. To enlarge the region upstream of the $\mathrm{Km}^{\mathrm{r}}$ cassette insertion site, we proceeded as follows: i) pUC115K was cut with EcoRI and KpnI, ii) pSKX312 was cut with $A c c \mathrm{I}$ and $E c o$ RI, and iii) the EcoRI-KpnI fragment from pSKX115 obtained in the first step and the AccI-EcoRI 775-bp fragment from the second step were purified and ligated each to the other and to EcoRI-KpnI treated pUC18 in a three-piece ligation to generate pUC115K+ (Fig. 1). For creation of a PXO99 mutant strain for both $\operatorname{raxR}$ and $\operatorname{raxH}$ (PXO99RH), a Sm${ }^{\mathrm{r}}$ gene ( $\Omega$ cassette) was introduced in the $B c l$ I site of the previously described ApoI 1,021-bp fragment subcloned into pUC18 generating pUCA1S. This construct was used for double homologous recombination to disrupt the raxR ORF in PXO99H. All constructs were first electroporated into $E$. coli DH10B cells, were verified by mini-preps and restriction assays, and were then used for insertional mutagenesis of $X$. oryzae pv. oryzae, according to Shen and associates (2001). Putative double recombinant strains were selected by $\mathrm{Km}^{\mathrm{r}}\left(\right.$ or $\mathrm{Sm}^{\mathrm{r}}$ ) and $\mathrm{Ap}^{\mathrm{s}}$ and were verified by PCR and Southern blot hybridization.

\section{Cloning of raxR and $\operatorname{raxH}$ for complementation and overexpression in $X$. oryzae pv. oryzae.}

The raxR and raxH coding sequences from PXO99 were PCR-amplified, using PXO99 genomic DNA as template and the following primers: RR_F (forward primer), 5'-CATATGCGGCTGCTGGTCATTG-3' (NdeI site shown in bold), and RR_R (reverse primer), 5'-GGATCCTTAGACATCGCTGCTGTC-3' (BamHI shown in bold) for raxR; and HK_FE (forward), 5'-GCTAGGTACCCGCATATGTCTAAACAGCGCCCCTTG-3' (KpnI and NdeI shown in bold), and HK_R2 (reverse), 5'-CGTAGGATCCTTAGCGAGCCGTGGCAGTAG3' (BamHI shown in bold) for $r a x H$. The PCR reactions were run in $1 \%$ agarose gels, and the raxR 726 -bp and $\operatorname{raxH} 1,318$ bp products were excised and purified. The $\operatorname{rax} R$ product was cloned into the pCR2.1 vector using the Original TA cloning kit (Invitrogen Corp., Carlsbad, CA, U.S.A.) to create pCRraxR. The raxH product was treated with KpnI and BamHI and was cloned into KpnI-BamHI cut pUC18 to create $\mathrm{pUCraxH}$. Following verification by sequencing, the $\operatorname{rax} R$ and $\operatorname{raxH}$ fragments were isolated using $\mathrm{NdeI}$ and $\mathrm{BamHI}$, were purified, and were ligated into NdeI-BamHI cut pET-15b, to generate $\mathrm{pETraxR}$ and $\mathrm{pETraxH}$, respectively. Using this strategy, a tag of six sequential copies of histidine (His $6 \times$ tag) was fused to the N-terminus of the coding sequences. The fused fragments were excised from these constructs using $X b a \mathrm{I}$ and HindIII and were cloned into the broad-range expression vector pML122 treated with the same restriction enzymes. In the resulting constructs, pMLraxR and pMLraxH, expression of the recombinant His $6 \times$-tagged proteins is under control of the pNm promoter (nptII, neomycin resistance), which is constitutively expressed in $X$. oryzae pv. oryzae. pMLraxR was electroporated into PXO99, PXO99R, and PXO99H. pMLraxH was electroporated into PXO99H. Transformants were selected by $\mathrm{Gm}^{\mathrm{r}}$, and plasmid insertion was confirmed by midi-preps and Western blots.

\section{Inoculation experiments for virulence assays.}

The $O$. sativa subsp. japonica rice varieties Taipei 309 (TP309, susceptible rice line) and 106-17-3-37, a TP309 transgenic line carrying the Xa21 gene (TP309-Xa21) (Song et al. 1995) were used in most experiments. One experiment was carried out using the $O$. sativa subsp. indica lines IR24 (suscepti- ble) and IRBB21 (carrying Xa21). For virulence assays with strains carrying avrXa7 and avrXa10, cultivars IRBB7 and IRBB10 (near-isogenic lines to IR24, carrying $\mathrm{Xa}$ 7 and $\mathrm{Xa10}$, respectively) and IR24 were used. Plants were grown in the greenhouse for six weeks and were transferred to the growth chamber for inoculation under the following conditions: 14-h days at $28^{\circ} \mathrm{C}$ and 10 -h nights at $24^{\circ} \mathrm{C}, 90 \%$ relative humidity. $X$. oryzae pv. oryzae strains were grown for $72 \mathrm{~h}$ at $28^{\circ} \mathrm{C}$ on peptone sucrose agar with appropriate antibiotics and were resuspended in sterile distilled water to a concentration of $10^{9} \mathrm{CFU}$ $\mathrm{ml}^{-1}$. Inoculation was carried out using the scissor-clip method (Kaufmann et al. 1973), cutting approximately $4 \mathrm{~cm}$ from the tip of fully expanded leaves with scissors dipped in the above bacterial suspensions. Lesion lengths were measured 14 dai. In planta growth curve experiments were carried out according to Song and associates(1995), and results represent averages from three inoculated leaves per strain per timepoint.

\section{Overexpression and purification \\ of recombinant His-RaxR from $E$. coli and production of anti-RaxR polyclonal antibodies.}

pETraxR was transformed into E. coli BL21(DE3)pLysS, and pilot small-scale experiments for optimization of protein expression and solubility were carried out according to standard procedures (The QIAexpressionist). Maximum overexpression of His-RaxR occurred following incubation with 1 $\mathrm{mM}$ IPTG at $37^{\circ} \mathrm{C}$ for $4 \mathrm{~h}$, and in all tested conditions (at different temperatures, IPTG concentrations, and incubation times), recombinant His-RaxR was found in the insoluble fraction (data not shown). Therefore, for purification of HisRaxR for production of antibodies, 500- to 1,000-ml cultures were incubated at $37^{\circ} \mathrm{C}$, following addition of $1 \mathrm{mM}$ IPTG, and His-RaxR was purified under denaturative conditions, using $\mathrm{Ni}^{2+}$-NTA resin (Qiagen), according to the manufacturer's instructions. Protein purification was verified by SDSPAGE and was confirmed by Western blot using anti-His $6 \times$ monoclonal antibodies (Sigma, St. Louis). Purified protein was used for raising polyclonal antibodies in a rabbit by standard procedures at the University of California-Davis Laboratory Animal Health Clinic.

\section{Expression of raxR in $X$. oryzae pv. oryzae cultures.}

For detection of RaxR in culture, $X$. oryzae pv. oryzae strains were grown for 24 or $48 \mathrm{~h}$ in $2 \mathrm{ml}$ of NB, peptone sucrose broth, or M9 minimal medium with appropriate antibiotics at $28^{\circ} \mathrm{C}$. Cells were centrifuged $\left(5,000 \times \mathrm{g}, 10 \mathrm{~min}, 4^{\circ} \mathrm{C}\right)$, and pellets were resuspended in $200 \mu \mathrm{l}$ of $1 \times$ SDS-PAGE loading buffer. Following a brief sonication (15 s in ice), samples were incubated at $90^{\circ} \mathrm{C}$ for $2 \mathrm{~min}$ and were stored at $-20^{\circ} \mathrm{C}$ until used for SDS-PAGE and Western blotting. All experiments were carried out twice with comparable results.

\section{Protein electrophoresis and Western blotting.}

Proteins were resolved in SDS-PAGE (with $12 \%$ polyacrylamide in the separating gel) and were stained with R250 Coommassie blue or were transferred to Hybond ECL nitrocellulose membranes (Amersham Pharmacia Biotech, Freiburg, Germany) by standard procedures (Sambrook et al. 1989). Membranes were incubated overnight in blocking solution consisting of $5 \%(\mathrm{wt} / \mathrm{vol})$ skimmed milk powder in T-TBS $(10 \mathrm{mM}$ Tris- $\mathrm{HCl}, \mathrm{pH} 8.0$, containing $150 \mathrm{mM} \mathrm{NaCl}$ and $0.1 \%$ [vol/vol] Tween 20). The membranes were then incubated in the presence of anti-His $6 \times$ monoclonal antibodies (Sigma) or anti-RaxR polyclonal antibodies at a dilution of 1:5,000 and 1:3,000, respectively, in T-TBS for $1 \mathrm{~h}$ at room temperature. Following three 10-min washes in T-TBS, the membranes were incubated for $1 \mathrm{~h}$ at room temperature in $\mathrm{T}$ - 
TBS containing 1:10,000 dilutions of anti-mouse IgG (Jackson ImmunoResearch Laboratories, Inc., West Grove, PA, U.S.A.) or anti-rabbit IgG (Cappel Laboratories, Durham, NC, U.S.A.) coupled to horseradish peroxidase. After three washes as described above, the membranes were incubated for $5 \mathrm{~min}$ with the Super Signal West Pico chemiluminescent substrate (Pierce, Rockford, IL, U.S.A.) and were developed by autoradiography using X-ray films (Fujifilm Medical Systems USA, Inc., Stamford, CT, U.S.A.).

\section{Construction}

of $\operatorname{rax} R$ and $\operatorname{rax} S T A B$ promoter-reporter constructs.

To clone the region containing the $\operatorname{rax} R$ promoter ( $\mathrm{pR} 1)$, a 381-bp fragment upstream of the $\operatorname{rax} R$ putative translation start codon was PCR-amplified, using pSKX312 as template and the following primers: PR1_F (forward primer), 5'CGCGGATCCACTGACCGGTCTGGACCAT-3' and PR1_R (reverse primer), 5'-CCGGAATTCTCCGGGGCGGCCCAG CAGGCA-3' (BamHI and EcoRI sites, respectively, are shown in bold). To clone the pST region, a 309-bp fragment upstream of the $\operatorname{rax} S T$ coding sequence was PCR-amplified, using p10.78 as template and the following primers: PST_F (forward), 5'-CGCGGATCCCGTCTGGTCATCTGC-3' and PST_R (reverse), 5'-CCGGTACCCCAAGCGTGCATCGT G-3' (BamHI and KpnI sites, respectively, are shown in bold). The $\mathrm{pR} 1$ and $\mathrm{pST}$ PCR products were purified and cloned into the promoterless- $g f p$ vectors pPROBE-NT (for $\mathrm{pR} 1$ ) and pPROBE-AT (for $\mathrm{pST}$ ) treated with appropriate restriction enzymes, to generate pPROBE-NT-pR1 and pPROBE-ATpST, respectively. A 212-bp fragment containing the $\mathrm{pNm}$ promoter (from nptII) was obtained by treatment of pML122 with SalI and XbaI and was cloned into pPROBE-AT cut with the same enzymes to create pPROBE-AT-pNm. The constructs were electroporated into E. coli $\mathrm{DH} 10 \mathrm{~B}$, and the resulting transformants were selected on Km or Ap. Following verification by restriction assays, all plasmids were electroporated into PXO99. pPROBE-AT-pST and pPROBE-ATpNm were also electroporated into PXO99R. To determine $g f p$ expression, cells were grown in NB with appropriate antibiotics and fluorescence was assessed using an RF-1501 Spectrofluorophotometer (Shimadzu Co., Kyoto, Japan), according to Miller and associates (2000). Cells were also observed in a Zeiss LSM 5 Pascal confocal microscope (Carl Zeiss, Inc., Thornwood, NY, U.S.A.), using standard settings for GFP detection (excitation and emission wavelengths of 488 and $505 \mathrm{~nm}$, respectively). Wild-type PXO99 and PXO99R carrying pPROBE-NT or pPROBE-AT were used as negative controls.

\section{ACKNOWLEDGMENTS}

We thank J. Leach, S. H. Choi, F. White, and S. E. Lindow for providing X. oryzae pv. oryzae strains and plasmids, and C. Dardick and J. S. Cha for valuable discussions during this study. The authors also thank $\mathrm{T}$. Ravid for his help with the confocal microscope. This project is being funded by National Science Foundation grant 0110483, National Institutes of Health grant GM55962, and grant 499/03 from the Israel Science Foundation. The work of S. Burdman at the University California-Davis was partially supported by a Lady Davis fellowship from The Hebrew University of Jerusalem. The work of S.-W. Lee was partially supported by a grant from the Korean Science and Engineering Foundation through the Plant Metabolism Research Center, Kyung Hee University, Suwon, Korea.

\section{LITERATURE CITED}

Alfano, J., and Collmer, A. 1997. The type III (hrp) secretion pathway of plant pathogenic bacteria: Trafficking harpins, avr proteins, and death. J. Bacteriol. 179:5655-5662.

Altschul, S. F., Madden, T. L., Schäffer, A. A., Zhang, J., Zhang, Z., Miler,
W., and Lipman, D. J. 1997. Gapped BLAST and PSI-Blast: A new generation of protein database search programs. Nucleic Acids Res. 25:3389-3402.

Ausubel, F. M., Brent, R., Kingston, R. E., Moore, D. D., Seidman, J. G., Smith, J. A., and Struhl, K. 1994. Current Protocols in Molecular Biology. John Wiley, NY, U.S.A.

Dangl, J. L., and Jones, J. D. 2001. Plant pathogens and integrated defence responses to infection. Nature 411:826-833.

da Silva F. G., Shen, Y., Dardick, C., Burdman, S., Yadav, R. C., De Leon, A. L., and Ronald, P. 2004. Bacterial genes involved in type I secretion and sulfation are required to elicit the rice $\mathrm{Xa21}$-mediated innate immune response. Mol. Plant-Microbe Interact. 17:593-601.

DeFeyter, R., Kado, C. I., and Gabriel, D. W. 1990. Small, stable shuttle vectors for use in Xanthomonas. Gene 88:65-72.

Dekkers, L. C., Bloemendaal, C. J. P., de Weger, L. A., Wijffelman, C. A., Spaink, H. P., and Lugtenberg, J. J. 1998. A two-component system plays an important role in root-colonizing ability of Pseudomonas fluorescens strain WCS365. Mol. Plant-Microbe Interact. 11:45-56.

Flor, H. H. 1971. Current status of the gene-for-gene concept. Ann. Rev. Phytopathol. 9:275-296.

Gomez-Gomez, L., and Boller, T. 2000. Fls2: An LRR-receptor like kinase protein involved in the perception of the bacterial elicitor flagellin in Arabidopsis. Mol. Cell 5:1003-1011.

Grebe, T. W., and Stock, J. B. 1999. The histidine protein kinase superfamily. Adv. Microb. Physiol. 41:139-227.

Hopkins, C. M., White, F. F., Choi, S. H., Guo, A., and Leach, J. E. 1992 Identification of a family of avirulence genes from Xanthomonas oryzae pv. oryzae. Mol. Plant-Microbe Interact. 5:451-459.

Jones, A. L., DeShazer, D., and Woods, D. E. 1997. Identification and characterization of a two-component regulatory system involved in invasion of eukaryotic cells and heavy-metal resistance in Burkholderia pseudomallei. Infect. Immun. 65:4972-4977.

Jones, D. A., Thomas, C. M., Hammond-Kosack, K. E., Balint-Kurti, P. J., and Jones, J. D. 1994. Isolation of the tomato $c f-9$ gene for resistance to Cladosporium fulvum by transposon tagging. Science 266:789-793.

Kaufman, H. E., Reddy, A. P. K., Hsieh, S. P. Y., and Merca, S. D. 1973. An improved technique for evaluating resistance of rice varieties to Xanthomonas oryzae. Plant Dis. Rep. 57:537-541.

Labes, M., Pühler, A., and Reinhard, S. 1990. A new family of RSF1010derived expression and $l a c$-fusion broad-host-range vectors for gramnegative bacteria. Gene 89:37-46.

Leach, J. E., and White, F. F. 1996. Bacterial avirulence genes. Ann. Rev. Phytopathol. 34:153-179.

Lindgren, P. B., Peet, R. C., and Panopoulos, N. J. 1986. Gene-cluster of Pseudomonas syringae pv. phaseolicola controls pathogenicity of bean plants and hypersensitivity on nonhost plants. J. Bacteriol. 168:512522.

Lukat, G. S., McCleary, W. R., Stock, A. M., and Stock, J. B. 1992. Phosphorylation of bacterial response regulator proteins by low molecular weight phospho-donors. Proc. Natl. Acad. Sci. U.S.A. 89:718-722.

McCleary, W. R., Stock, J. B., and Ninfa, A. J. 1993. Is acetyl phosphate a global signal in Escherichia coli? J. Bacteriol. 175:2793-2798.

Miller, M. B., Skorupski, K., Lenz, D. H., Taylor, R. K., and Bassler, B. L. 2002. Parallel quorum sensing systems converge to regulate virulence in Vibrio cholerae. Cell 110:303-314.

Miller, W. G., Leveau, H. J., and Lindow, S. E. 2000. Improved $g f p$ and inaZ broad-host-range promoter-probe vectors. Mol. Plant-Microbe Interact. 13:1243-1250.

Nes, I. F., and Eijsink, H. H. 1999. Regulation of group II peptide bacteriocin synthesis by quorum-sensing mechanisms. Pages 175-192 in: Cell-Cell Signaling in Bacteria. G. M. Dunny and S. C. Winans, eds. American Society for Microbiology, Washington, D.C.

Noël, L., Thieme, F., Nennstiel, D., and Bonas, U. 2001. cDNA-AFLP analysis unravels a genomic-wide $h r p G$-regulon in the plant pathogen Xanthomonas campestris pv. vesicatoria. Mol. Microbiol. 41:12711281 .

Prentki, P., and Krisch, H. M. 1984. In vitro insertional mutagenesis with a selectable DNA fragment. Gene 29:303-313.

Roland, K. L., Martin, L. E., Esther, C. R., and Spitznagel, J. K. 1993 Spontaneous pmrA mutants of Salmonella typhimurium LT2 define a new two-component regulatory system with a possible role in virulence. J. Bacteriol. 175:4154-4164.

Sambrook, J., Fritsch, E. F., and Maniatis, T. 1989. Molecular Cloning: A Laboratory Manual. Cold Spring Harbor Laboratory Press, Cold Spring Harbor, NY, U.S.A

Sanger, F., Nicklen, S., and Coulson, A. R. 1977. DNA sequencing with chain-terminating inhibitors. Proc. Natl. Acad. Sci. U.S.A. 74:5463-5467.

Shen, Y., Chern, M.-s., da Silva, F. G., and Ronald, P. 2001. Isolation of a Xanthomonas oryzae pv. oryzae flagellar operon region and molecular characterization of $f l h F$. Mol. Plant-Microbe Interact. 14:204-213. 
Shen, Y., Sharma, P., da Silva, F. G., and Ronald, P. 2002. The Xanthomonas oryzae pv. oryzae $\operatorname{rax} P$ and $\operatorname{rax} Q$ genes encode an ATP sulfurylase and APS kinase that are required for AvrXa21 avirulence activity. Mol. Microbiol. 44:37-48

Song, W. Y., Wang, G. L., Chen, L. L., Kim, H. S., Pi, L. Y., Holsten, T. Gardner, J., Wang, B., Zhai, W. X., Zhu, L. H., Fauquet, C., and Ronald, P. C. 1995. A receptor kinase-like protein encoded by the rice disease resistance gene, Xa21. Science 270:1804-1806.

Stock, A. M., Robinson, V. L., and Goudreau, P. N. 2000. Two-component signal transduction. Ann. Rev. Biochem. 69:183-215.

Thompson, J. D., Higgins, D. G., and Gibson, T. J. 1994. CLUSTAL W: Improving the sensitivity of progressive multiple sequence alignment through sequence weighting, positions-specific gap penalties and weight matrix choice. Nucleic Acids Res. 22:4673-4680.

Tsuchiya, K., Mew, T. W., and Wakimot, S. 1982. Bacteriological and pathological characteristics of wild-types and induced mutants of Xanthomonas campestris pv. oryzae. Phytopathol. 72:43-46.

Wang, G. L., Song, W. Y., Ruan, D. L., Sideris, S., and Ronald, P. C. 1996. The cloned gene, $X a 21$, confers resistance to multiple Xanthomonas oryzae pv. oryzae isolates in transgenic plants. Mol. Plant-Microbe Interact. 9:850-855.

Wang, G. L., Ruan, D. L., Song, W. Y., Sideris, S., Chen, L., Pi, L. Y., Zhang, S., Zhang, Z., Fauquet, C., Gaut, B. S., Whalen, M. C., and
Ronald, P. C. 1998. Xa21D encodes a receptor-like molecule with a leucine-rich repeat domain that determines race-specific recognition and is subject to adaptive evolution. Plant Cell 10:765-779.

West, A. H., and Stock, A. M. 2001. Histidine kinases and response regulator proteins in two-component signaling systems. Trends Biochem. Sci. 26:369-376.

Yang, B., Zhu, W., Johnson, L. B., and White, F. F. 2000. The virulence factor AvrXa7 of Xanthomonas oryzae pv. oryzae is a type III secretion pathway-dependent nuclear-localized double-stranded DNA binding protein. Proc. Natl. Acad. Sci. U.S.A. 97:9807-9812.

Zhu, W., Magbanua, M. M., and White, F. F. 2000. Identification of two novel $h r p$-associated genes in the hrp gene cluster of Xanthomonas oryzae pv. oryzae. J. Bacteriol. 182:1844-1853.

\section{AUTHOR-RECOMMENDED INTERNET RESOURCES}

Xanthomonas Genome Projects website: genoma4.iq.usp.br/xanthomonas

National Center for Biotechnology Information: www.ncbi.nlmnih.gov

Washington University in St. Louis Pfam protein search: pfam.wustl.edu/hmmsearch.shtml

SMART database: smart.embl-heidelberg.de 